\title{
Adaptace a vzdělávání pracovníků v prostředí výrobních podniků - nové trendy
}

\author{
Alena Lochmannová \\ Západočeská univerzita v Plzni, Fakulta strojní, Katedra průmyslového inženýrství a \\ managementu \\ Univerzitní 2732/8, 30614 PIzeň, Česká republika \\ lochmann@fzs.zcu.cz
}

\begin{abstract}
Anotace: Příspěvek je výsledkem rešeršní činnosti v prvním ročníku studia doktorského studijního programu a jako takový představuje první dílčí podklad pro zpracování vlastní disertační práce. Zabývá se problematikou adaptace a vzdělávání zaměstnanců ve specifických podmínkách s využitím virtuální reality, přičemž především představuje prípadové studie se zdưrazněním nového využití virtuální reality pro zapracování, adaptaci, ukotvení a následný rozvoj zaměstnanců.
\end{abstract}

\section{1 Úvod}

Využití VR ve vzdělávání je jedním z přirozených vývojových kroků učiněných $\checkmark$ rámci školení s využitím počítačů (CBT). Použití počítače jako pomůcky pro výuku se datuje do padesátých let a seriózní studia začínají v šedesátých letech. Příchod mikropočítače v roce 1977 umožnil, aby se osobní počítač stal nepopiratelně efektivním systémem pro mnoho aspektů učení. VR, kterou Ize použít na všech typech počítačů, sledovala tento trend [57]. Virtuální realitu však nelze zaměňovat se simulovanou realitou (SR). Jakmile je hráč ponořen do simulace nebo hry, získává pocit přítomnosti v prostředí spíše než jen pocit pozorování prostředí zvnějšku. Senzorická zpětná vazba umožňuje selektivní poskytování senzorických dat o prostředí na základě vstupu uživatele. Konečnou charakteristikou, která je nezbytná pro replikaci reality, je interaktivita, což je schopnost procházet vytvořeným světem, interagovat $s$ objekty, postavami a místy [13]. Základem vzdělávacího nástroje VR je možné vytvořit tyto prvky.

Kvůli potenciálním úrovním realismu si vědomé mysli v simulaci nemusí být vědomy, že jejich realita není do jisté míry pravá. Brey [12] tvrdí, že v důsledku toho se objevuje mnoho problémů kolem etiky. Jedním ze tř́ důvodů, které se mohou jevit jako morálně problematické, je především nedodržení standardů přesnosti a zkreslení reality. Za druhé, nedodržování norem spravedlivosti, a tím nespravedlivého znevýhodňování určitých skupin. A konečně, porušení standardů slušnosti a veřejné morálky. Proto je důležité, aby konstruktéři simulačních nástrojů toto zohlednili při vytváření simulačního softwaru, který funguje jako nástroj pro vzdělávání. Bylo by morálně nepřípustné navrhnout svět, který ohýbá hodnoty uživatele $\mathrm{k}$ hodnotám návrháře. 
VR jako termín nemá žádný standardní význam, nikoli $v$ rámci samoobslužného VR průmyslu. To je způsobeno tím, že se tento termín může kvalifikovat jako jakékoli vizuální reprezentační médium, jako je televize nebo obrazy. VR spadá do dvou kategorií projekční VR a desktop VR. Projekční VR zahrnuje trojrozměrné (3D) virtuální modely promítané do místnosti, kterou Ize vnímat $z$ různých perspektiv (CAVE). Desktop VR se týká prostředí znázorněného na obrazovce počítače, které lze vnímat stereoskopicky pomocí speciálních brýlí [12]. Tento projekt využívá obrazovku Zspace, což je desktop VR. To by umožnilo príijatelný přechod pro návrháře založené na 3D modelování a snížilo by se zdráhání zaměstnanců přijímat nový systém designu. Burke [15] uvádí, že je lepší zpozdit implementaci, než riskovat selhání z důvodu nedostatečného vedení nebo neochoty zaměstnanců používat nový systém [15].

Shiratuddin a Zulkifli [63] tvrdí, že pokroky $v$ počitačovém modelování, vizualizaci, simulaci a správě dat o výrobcích činí z VR životaschopné alternativy $\mathrm{k}$ tradičním procesům realizace produktů ve výrobě. Její použití $v$ průmyslu umožňuje společnostem snižit náklady na design a výrobu a dále zajistit kvalitu produktu. $V$ důsledku toho se zkracuje čas potřebný $k$ přechodu od návrhu koncepce $k$ výrobě. To však nenaznačuje, že implementace VR zlepší jakoukoli společnost plošně. Burke [15] tvrdí, že používání technologie ke zvýšení efektivity stále vede $\mathrm{k}$ tomu, že implementátor stále rozkládá pevné myšlenky $v$ rámci organizace. Kromě toho by toto nalezení správného technologického řešení základních problémů společnosti nemohlo být dále od pravdy. Úspěch a schopnost řídit určují lidské faktory při realizaci projektu.

Chceme-li vytvořit simulaci, která má schopnost učit uživatele komplexní informace, musí zůstat prííjemná a neustále poutavá. Je třeba hledat rovnováhu mezi obtížným a dokončitelným. V odvětví videoher se to již ukázalo, pokud by hra byla neskutečně těžká, nikdo by ji nekoupil. Hráči také nechtějí, aby byl obsah hloupý nebo zkrácený [28]. Gee [27] uvádí, že problémy prezentované hráči musí být racionálně strukturovány, práce $v$ kognitivní vědě ukazuje, že hráči, kteři se zabývají problémy, které vytvářejí dobré zobecnění pro pozdější problémy, se mají šanci dozvědět více.

VR hrála v posledních 60 letech $v$ designu a výrobě převládající roli [13]. To je způsobeno rozšiřováním výkonu a schopností softwaru $v$ důsledku jevu známého jako Mooreův zákon. Zde se výkon integrovaných obvodů zdvojnásobuje príibližně každých osmnáct měsíců. To se týká téměř všech elektronických zařizení, protože obsahují integrované obvody [51]. Při pohledu na tuto historii je obtížné odmítnout integraci VR do moderní výroby. VR $v$ doslovném smyslu by byla CAD a v podstatě cokoli, co by bylo vidět na obrazovce počítače, tato nejednoznačnost umožňovala tolik potřebnou specifičnost při definování VR.

Ponoření (imersion) je často termín používaný $\mathrm{k}$ definování různých účinků, které různé formy VR přinášejí. Costello [18] rozpracoval definici VR více než Shiratuddin a Zulkifli [63] tím, že popsal rưzné úrovně dostupné VR, zacílil 
pritom na pocit ponoření. Je třeba přihlížet $k$ tomu, jak silná je pozornost uživatele zaměřena na daný úkol.

Existují i další výhody pro výrobce plynoucí z príjetí VR na pracovišti než simulace komplexních systémů $s$ aspekty ponoření a interaktivity. Je třeba zvážit také flexibilitu a prizpưsobivost, kterou toto médium poskytuje; měla by být zohledněna schopnost simulovat potenciální výsledky s vysokou mírou přesnosti. Existuje také potenciál vizualizace makroskopického a mikroskopického [38].

V posledních letech VR průmysl zaujal zajímavý obrat. Společnost Occulus Rift byla zakoupena společností Facebook $s$ úmyslem ji vyvinout na více než jen herní platformu. Skutečnost, že to může udělat společnost velikosti Facebook, znamená, že pro tyto platformy platí značný potenciál. Ukazuje také, že tato technologie dosáhla cenové dostupnosti. Před třiceti lety, kdy Jaron Lanier založil VPL, by náhlavní soupravy VR stály až 100000 dolarů [58].

Společnost Occulus Rift také inspirovala další společnosti, aby následovaly postup $v$ závodě směrem $\mathrm{k}$ domácímu hernímu systému VR. Společnost Sony začala vyvíjet HMD, který bude dalším hardwarem pro PlayStation 4. Zatímco videohry jsou místem, kde se vylepšený $V R$ rozběhne, ukazuje se již jeho prítomnost $v$ architektuře, CAD, výcviku reakce na mimořádné situace a terapii fobií [58]. Má potenciál stát se nákupním a hudebním formátem, díky kterému je tato technologie součástí nové éry integrace $s$ výpočetní technikou.

VR ve výrobním slova smyslu vytvořilo pojem Virtual Manufacturing (VM). Depince a Chablat [22] jednoduše definovali VM jako nic jiného než výrobu v počítači. To je dále rozpracováno Iwatou a kol. [36], kteří definují VM jako výrobu virtuálních produktů definovaných jako agregace počítačových informací, které poskytují reprezentaci vlastností a chování aktualizovaného produktu.

\section{Adaptace zaměstnanců výrobního podniku - nové trendy}

\subsection{Diskuze Game based learning}

Poměrně zajímavý konceptem je tzv. game based learning. Děti a dospělí nemají stejné styly učení ani kognitivní zátěž. Videohry však přicházejí v mnoha věkových rozsazích, takže obsah nemusí být pro děti zjednodušován, ve skutečnosti to mnozí dospělí sběratelé nesnášejí [28]. Hry také přicházejí s řadou obtíží, ze kterých si může uživatel vybrat, což dále umožňuje hráči specifikovat styl hry a možnosti učení. Některé hry jdou až tak daleko, že navrhují hráči změnit jejich obtížnost na základě úspěchu nebo neúspěchu při hrách. Hocine a Gouaïch [33] uvádějí, že tuto techniku přizpůsobení obtižnosti Ize použít $v$ jiných formách simulace, jako je rehabilitace. Stejně 
jako rehabilitační proces musí být simulace přizpůsobena uživateli. Například pacient používající simulaci může mít jinou formu zranění než jiná. Proto musí být vytvořen systém, který uživateli umožní přizpưsobit herní zážitek.

Opora (scaffolding) je efektivní forma výuky videoher. Príkladem toho jsou výukové fáze hry, kdy se hráč učí základní dovednosti pro navigaci ve hře. Jsou jim předvedeny ukázky, jak provést určitou akci; to dává hráči potřebné dovednosti $\mathrm{k}$ dokončení požadovaného úkolu, který již viděli, že se odehrává. Wainess, Kerr a Koenig [73] provedli studii analyzováním instruktivního obsahu $v$ rámci řady populárních her, jedním z těchto instruktivních konstrukcí bylo poskytování opory. To bylo dále rozděleno na podkategorie poskytování cílů, seznamů úkolů, organizátorů předem, seznamů zdrojů, nápověd, zpětná vazba a zpracované príklady. To naznačovalo, že tyto aspekty jsou klíčové, když hráči poskytují instruktivní oporu během přípravných fází hry nebo simulace [2]. Výsledkem studie bylo, že hry, které obsahovaly velké množství instruktážních opor, usnadňují učení hry. Stejně tak se Ize domnívat, že i výukové programy s dostatečnou oporou mohou zefektivnit osvojení si príslušné operace $v$ rámci výroby.

\subsection{Využití VR v př́padě studentů technických oborů}

Prípadová studie Virtual Reality Case Study throughout the Curriculum to Address Competency Gaps provedená Whitmanem, Malzahnem, Madhavnem, Wehebou a Krishnanem [77] zkoumala implementaci VR jako vzdělávacího nástroje pro studenty technických oborů, kteří opouštějí univerzitu a vstupují do průmyslu. Zjistilo se, že studenti shledávali jako obtižné prakticky použít teoretické informace, které se naučili, $v$ prostředí průmyslového podniku. Jasné řešení bylo nalezeno, když se studenti účastnili simulace VR pro prostředí štíhlé výroby. Další modul kurzu se zaměřil na stejnou simulaci, kde byl snížen počet pracovních stanic a změněny doby procesu, aby bylo možné $v$ určitých oblastech hromadit zásoby. Tím se studenti učili o nedostatcích $v$ rámci dané továrny, což jim umožnilo získat realistické porozumění tomu, jak se vypořádat $s$ problémy, které mohou nastat $v$ továrně.

\subsection{Další obory vzdělávání a sledování pokroku studentů}

Aplikace virtuální reality mají velký potenciál pro použití ve vzdělávání na všech úrovních. Rozhraní VR mají potenciál doplňovat stávající príistupy ve vzdělávání. Ve virtuálních světech mohou být studenti/školení jedinci/zaměstnanci současně vybaveni trojrozměrnými reprezentacemi, více pohledy a referenčními rámci, simultánními vizuálními a zvukovými zpětnými vazbami. S pečlivým návrhem a implementací mohou být tyto schopnosti syntetizovány tak, aby vytvořily hluboký pocit motivace a koncentrace vedoucí k zvládnutí složitých materiálů. Bylo vyvinuto několik vzdělávacích aplikací. Shin ohlásil stolní VR systém pro výuku prírodních věd $v$ oblasti věd o Zemi pro studenty středních škol [62]. Simulace VR byly vyvinuty pro výuku vědeckých konceptů, jako je radiační rovnováha, zemětřesení viny, pohyb 
oceánu a rovnováha zemské kůry. Virtuální nástroj plynového chromatografuhmotnostního spektrometru byl zřízen v prostředí webu, aby školil studenty $v$ provozu př́stroje [74]. Studenti se naučí ovládat virtuální nástroj prostřednictvím webové stránky mimo laboratoř, čímž se nástroj uvolní pro použití $v$ laboratoři pro provádění smysluplných experimentů a shromažd'ování dat. Byt' se nejedná o průmyslové prostředí, princip aplikace zůstává stejný. Studie „Virtual reality simulations and animations in a webbased interactive manufacturing engineering module" [55] představuje vývoj webového interaktivního výukového balíčku, který využívá simulace a animace VR, pro třetí ročník modulu počitačově automatizovaných výrobních systémů (CAMS) ve výrobní divizi na Národní univerzitě v Singapuru. Značkovací jazyk HyperText (HTML) se používá pro zobrazování informací, vkládání appletů Java a plug-inů pro modelování jazyka virtuální reality (VRML). Simulace VR a animace NC obráběcích operací byly vytvořeny pomocí VRML a Java. VRML se používá $k$ vytváření virtuálních $N C$ obráběcích prostředí. Java applety se používají $k$ provádění simulací a animací. Byly implementovány dvourozměrné (2D) simulace, které demonstrují pohyby nástrojů NC kódů. Existuje několik interaktivních $2 \mathrm{D}$ appletů, jejichž chování závisí na vstupu dat od uživatelů. Pro použití VRML jsou poskytovány trojrozměrné (3D) simulace. Mnoho z těchto simulací VR vygeneruje interakce mezi Java a VRML, které vyžadují uživatelské vstupy pomocí techniky EAI (External Authoring Interface). Zobrazení světů VRML bude vyžadovat použití modulu Cosmoplayer. Byly také implementovány výukové otázky a nástroj pro sledování pokroku studentů. Do tohoto projektu je začleněn monitorovací nástroj, konkrétně Flying Fish vyvinutý vědci z University of Western Australia, aby sledoval pokrok studentů. Je to výukové prostředí, které je schopné sledovat pokrok studentů, stanovit termíny a udělovat známky. Prostředí Flying Fish umožňuje administrátorům a přednášejícím stanovit výukové otázky, které jsou podporovány Java. Zabezpečení je improvizováno, protože studenti se musí prihlásit pomocí vydaných hesel. Takový monitorovací systém je pohodlný a užitečný, protože není možné sledovat pokrok každého studenta $v$ běžných lekcích tutoriálu.

\subsection{VR a vzdělávání $v$ těžebním průmyslu}

Studie Virtual Reality Training Applications for the Mining Industry [72] přibližuje využití virtuální reality $\vee$ prostředí dolů. $\vee$ kontextu důlní těžby je primární zájem užití a dalšího rozvoje virtuálního prostředí umožnit důlním pracovníkům vyzkoušet si a zažít důlní situaci, aktivity a procesy, s nimiž se mohou $v$ rámci každodenních aktivit $v$ tomto prostředí setkat. Bezpečné a efektivní plánování a produkce jsou základem $k$ ziskové důlní těžbě a VR poskytuje intuitivní nástroje pro prozkoumání různých a často nesourodých informací spojených s důlními procesy. Přitom je nutno podotknou, že těžba v jedenadvacátém století je moderním průmyslem, který usiluje o redukci rizik a zlepšuje bezpečnost prostřednictvím použití technologií, které jsou často vyvinuty $v$ rámci jiných průmyslových odvětví. Interaktivní systém $\mathrm{CB}$ vizualizace je príkladem. Milgram a Kishino [49] si uvědomili, že zatímco 
virtuální prostředí napodobují vlastnosti a zákony skutečného světa i mimo něj, často se přehlíží, že virtuální realita může být spojena $s$ jinými prostředími. To znamená, že virtuální světy Ize rozširíit o skutečné obrázky a data. Pro těžební operace představuje VR silný nástroj jak z hlediska provozu, tak z hlediska školení, kde Ize syntetické obrazy odvozené z prediktivních dat kombinovat a překrývat obrazy a zkušenosti ze skutečného světa. $V$ rámci studie Virtual Reality Training Applications for the Mining Industry [49] byly nainstalovány různé prototypové systémy $V R$ a použity $v$ dolech a hutích. Všechny byly dobře přijaty a poskytly zajímavou a poutavou alternativu $k$ běžným školicím programům. Současně tento přístup zlepšil kulturu bezpečnosti a informovanost pracovníků. Obdobným prostředím a tématem se zabývají i další studie, mezi nimi např. Virtual Reality for Mine Safety Trainin [25]. Cílem projektu školení o důlní bezpečnosti je vyvinout dostupné programové vybavení, které bude fungovat na dostupných počítačích a poskytne horníkům realistický tréninkový zážitek. $V$ zájmu dosažení tohoto cíle se vědci zaměřují na dva samostatné, ale paralelní úkoly. Prvním úkolem je vývoj evakuačního výcvikového softwaru s využitím existujícího počítačového grafického enginu. Druhá úloha se týká vývoje simulátoru rozpoznávání nebezpečí pomocí herního softwaru off-the-shelf. Výcvikový software vyvinutý pro obě zařízení je navržen pro provoz na levných osobních počítačích vybavených trojrozměrnými grafickými kartami. K dokončení prvního úkolu, který se ve vazbě na moji disertační práci jeví jako zajímavější a využitelnější, se výzkumníci opírali o grafický engine 3DGE zakoupený od Twilight 3D ve finském Vantagu. Grafický stroj zpracovává scénu v rámci virtuálního dolu. $\mathrm{C}++$ kód byl vyvinut na zakázku pro fyziku (jako je gravitace) a interakce ve virtuálním dole. Tento systém navržený na míru byl nezbytný pro úkol evakuačního výcviku, protože může akceptovat skutečnou geometrii dolu odstraněnou $z$ důlních map. Tato vlastnost je nezbytná $k$ tomu, aby poskytla praktikantům realismus a umožnila evakuační cesty, které se praktikují stejně, jako by tomu bylo v případě běžného dolu. Systém navržený na zakázku také umožňuje přizpůsobit uživatelská rozhraní a interakce pro těžební průmysl. $\vee$ závislosti na popisu práce školeného a na tom, jak chce trenér simulaci provést, Ize procvičit různé scénáře pro evakuační výcvik. Současný program umožňuje, aby praktikant začal na povrchu dolu $v$ místnosti $\mathrm{s}$ bezpečnostním zařízením. Zde účastník získá potřebné bezpečnostní vybavení před zahájením práce. Jedinec pak postupuje do podzemí přes klec, aby zahájil směnu $v$ určeném pracovním prostoru. Když školenec dorazí do správné pracovní oblasti, na obrazovce se objeví varovné hlášení, které uvádí, že došlo $k$ havárii $v$ dole, což je indikováno zápachem plynu nebo blikajícími světly. Stážista musí poté opustit důl a prìtom dodržovat správné postupy a trasy. Scénář lze změnit tak, aby testoval reakci účastníka na blokovanou primární únikovou cestu, takže musí být použita sekundární úniková cesta. 


\subsection{VR a kolaborativní roboti}

$\checkmark$ moderních výrobních systémech vznikla potřeba spolupráce a sdílení průmyslových robotů a lidí v pracovním prostoru za účelem plnění výrobních úkolů. Cílem této koexistence a spolupráce je zlepšit kvalitu a produktivitu zlepšením senzorických schopností, znalostí a obratnosti pracovníků v ručně prováděných úkolech pomocí síly, přesnosti a opakovatelnosti činností robotů. $\checkmark$ takovém prípadě namísto toho, aby lidská práce byla nahrazena roboty při opakujících se úkolech, může spolupráce robotů s pracovníky vést $k$ „práci s príidanou hodnotou“. V tomto kontextu se jako zajímavá jeví studie „Design of a virtual reality training system for human-robotcollaboration in manufacturing tasks“ [47]. Nedávné studie interakce lidí a robotů ukázaly, že plynulá spolupráce (nad rámec typu interakce typu "stop and go") vyžaduje informovanost a předvídání záměru jak lidských, tak robotických [34]. Situační povědomí Ize definovat jako „vnímání prvků v prostředí v množství času a prostoru, chápání jejich významu a projekce jejich stavu v blízké budoucnosti“ [76]. Aby bylo možné toto povědomí a očekávání usnadnit, je důležité, aby lidé i roboti sdělovali svůj stav, umístění a záměr, a to bud' výslovně prostřednictvím určitých podnětů, jako jsou zvukové / vizuální signály, nebo implicitně prostřednictvím svých akcí a pohybových cest [70]. $V$ takových prípadech jsou přednostně nasazovány hry (serious games) a vysoce interaktivní a pohlcující tréninkové aplikace virtuální, rozšířené nebo smíšené reality, protože mohou poskytovat zdokonalený výcvik ve všech třech úrovních uvědomění si situace (vnímání, porozumění a projekce). Výše uvedená studie prezentuje vysoce interaktivní a pohlcující VRTS („beWare of the Robot") ve smyslu seriózní hry, která v reálném čase simuluje spolupráci mezi průmyslovými robotickými manipulátory a lidmi a provádí jednoduché výrobní úkoly. Prezentovaný scénář zahrnuje spolupráci při pokládání pásek pro výrobu leteckých kompozitních dílů. Problémy s bezpečností, jako jsou kontakty a srážky, se reš̌i hlavně „mimořádnými událostmi“, tj. varovnými signály, pokud jde o vizuální podněty a zvukové poplachy. Duševní bezpečnost má nejvyšší prioritu a postup je takový, že varovné podněty uvnitř VRTS, které nabízejí ponoření a interakci $v$ reálném čase, mohou uživateli poskytnout zvýšené situační povědomí a zvýšené vnímání pohybu robota. Krátkodobým cílem výzkumu je prozkoumat rozšiřené zkušenosti a chování uživatelů ve virtuálním světě, zatímco spolupracují s robotem, zatímco celkovým dlouhodobým cílem je prozkoumat přijatelnost spolupráce člověkrobot a zlepšit příslušné podmínky pomocí takového prostředí. Byl vyvinut scénář použití, představující kolaborativní páskové pokládání člověk-robot pro stavbu vyztužených kompozitních dílu $v$ leteckém průmyslu. Obvyklé pokládání pásky typicky zahrnuje vyztužení uhlíkových vláken ve formě profilovaných textilních vrstev (náplastí / tkanin), které jsou ručně stohovány operátorem uvnitř formy, postupně na sebe, dokud není dosaženo požadované tloušt'ky. Ve scénáŕi spolupráce člověk-robot je robotickému manipulátoru priiřazen sběr a přenos náplastí na člověka. Jakmile uživatel vezme náplast $z$ robota a umístí ji na správné místo uvnitř kovové matrice umístěné před sebou, robot pokračuje v podávání další náplasti. Tento postup 
se opakuje, dokud člověk řádně neumístí všechny různé náplasti, což je v rukou avatara. Tyto prímé úkoly spolupráce člověk-robot jsou udržovány co nejjednodušší, ale zahrnují těsnou blízkost mezi člověkem a robotem a jsou prováděny paralelně, jako scénář „manipulace“ $z$ ruky do ruky. Ten byl vybrán tak, aby představoval typické výrobní scénáře člověk-robot pro spolupráci, aby bylo zajištěno další využití v budoucnosti [47].

\section{6 Školení ve VR a výrobní procesy}

Zpracovatelský průmysl nejvíce přispívá k prosperitě průmyslových zemí. Je však stále obtížnější vyhovět požadavkům zákazníků a konkurovat jim. Pokroky $v$ technologii virtuální reality poskytly aplikační VR pro různé inženýrské aplikace, jako je návrh produktu, modelování, řízení dílny, simulace procesů, plánování výroby, školení, testování a ověřování. VR má ve výrobních aplikacích velký potenciál $\mathrm{k}$ řešení problémů před tím, než se použije $v$ praktické výrobě, čímž se zabrání nákladným chybám. VR nejenže poskytuje prostředí pro vizualizaci $v$ trojrozměrném prostředí, ale také pro interakci s objekty, aby se zlepšilo rozhodování jak z kvalitativního, tak z kvantitativního hlediska. Aplikace virtuální reality ve výrobě byly $v$ rámci studie Virtual reality applications in manufacturing system [31] rozděleny do tří skupin; návrh, výrobní procesy a řízení provozu. Pro mě jako nejzajímavější ve vazbě na možnost školení a adaptace zaměstnanců (resp. školení v rámci adaptace zaměstnanců) se jeví část "výrobní procesy“. Toto bylo rozděleno do tři různých oblastí; obrábění, montáž a kontrola. Virtuální obrábění zahrnuje procesy řezání, jako je soustružení, frézování, vrtání a broušení atd. Obrábění pomocí virtuální reality se zabývá hlavně procesy řezání, jako je soustružení, frézování, vrtání a broušení atd. Obrázek níže ukazuje, že technik simuluje pomocí VR použití hexapodového obráběcího stroje. Uživatel může namontovat obrobek na frézce, vybrat nástroj a provádět prímé obráběcí operace, jako jsou axiální pohyby nebo předdefinované sekvence [5].

Virtuální sestavení je klíčovou součástí virtuální výroby a je definováno jako použití počítačových nástrojů $\mathrm{k}$ vytváření nebo pomoci $\mathrm{s}$ technickými rozhodnutími souvisejícími se sestavením pomocí analýzy, predikčních modelů, vizualizace a prezentace dat bez realizace produktu nebo podpůrných procesů. Virtuální realita může být použita pro montáž / demontáž. $\vee$ montážní lince se virtuální výroba používá hlavně ke zkoumání montážních procesů, mechanických a fyzikálních charakteristik na základě modelování a simulace [37].

$\checkmark$ roce 2006 Toyota využila virtuální osobu, tzv. Ergo Mana, aby pomohla snížit fyzické zatižení montážních pracovníků, kteří stavěli novou generaci Camry ve svém výrobním závodě $v$ Melbourne. Byl použit jako součást inovativní operace 3D virtuální montáže, která digitálně replikovala celý proces výroby sestavy [31]. Další VR aplikací v montáži je společnost Ford Motor Company, která uzavřela partnerství se společností Siemens při budování technologie virtuálních montážních závodů. Aplikace $s$ názvem 
IntoSite používá infrastrukturu Google Earth, která uživatelům umožňuje procházet 3D verze skutečných montážních závodů Ford přímo na jednotlivých pracovních stanicích. Umožnit technikưm pohybovat se s částmi a procesy prakticky znamená efektivnější společnost. Bez ohledu na to, jak automatizovaný a virtuální se proces výroby automobilů stává, vozidla jsou nakonec vyrobena lidmi. Čím lepší je komunikace mezi těmi lidmi, tím lepší produkt jsou schopni vytvořit. Naštěstí IntoSite neumožňuje technikům pouze prakticky cestovat do montážních závodů po celém světě, ale také je lépe propojí se svými globálními kolegy. Díky tomuto prístupu sjednocené komunikace mohou spolupracovníci na celém světě odpovídat na otázky okamžitě, data Ize sdílet $v$ reálném čase a dokonce i cestovní náklady by se mohly potenciálně snížit.

Virtuální výrobní technologie se používá k modelování a simulaci inspekčního procesu a fyzikálních a mechanických vlastností inspekčního zařizení. Tato virtuální inspekce poskytuje prostředí pro studium metodik inspekce, detekce kolizí, plánu inspekce a faktorů ovlivňujících přesnost inspekčního procesu [40].

\subsection{Využití VR v automotive}

Za zmínku jednoznačně stojí studie „Implementing virtual reality into employee education in production sector of automotive industry: creating worker training for assembling car dashboard in virtual reality" [19]. Vývoj informačních a komunikačních technologií umožnil nové způsoby zpracování a umožnil inovaci zavedených metod a technik. V oblasti vzdělávání poskytují IKT interaktivní a atraktivní vzdělávání v prostředí virtuální reality $s$ vysokou podobností s fyzickou realitou. Žáci získávají nové znalosti prostřednictvím pokusů a selhání $v$ dynamickém a interaktivním prostředí, které poskytuje empirické zkušenosti „učení se praxí. Výše uvedená studie navrhla implementaci virtuální reality do vzdělávání zaměstnanců ve výrobním sektoru montáže přístrojové desky $v$ automobilovém průmyslu. Nastínila a popsala proces vývoje takového školení s výpočtem odhadovaných nákladů, aby poskytla více poznatků o používání virtuálních technologií ve vzdělávání široké veřejnosti. Náklady na autory popsané řešení Ize odhadnout na přibližně 20000 EUR, prričemž 3,000 EUR představují náklady na hardware. Tento výpočet odhadovaných nákladů nezahrnuje cestovní náklady na jednotlivé návštěvy na straně zákazníka ani žádné ziskové rozpětí prodávajícího ani rizikové náklady. Postupy projektového rízení tradičně doporučují zvýšit odhadovaný výpočet přibližně o 20-30\%, aby zahrnoval ziskové rozpětí a náklady vyvolané projektovým rizikem. Takové príikazy však obvykle nejsou pouze pro simulaci jedné činnosti, ale více činností podobných procesů, např. montáž různých palubních desek automobilů $s$ různým vzhledem, ale $s$ podobným montážním scénářem. $V$ takovém prípadě Ize odhadnout, že každá další řídicí deska s podobným průběhem procesu montáže na podobném / stejném pracovišti představuje další náklady ve výši 5000 EUR. Tyto odhadované náklady zahrnují použití stávající logiky a scény pro nové komponenty. Pro výše uvedený výpočet byly jako reference použity 
sazby specializovaných společností v daném oboru na Slovensku, protože jde o velmi úzký segment s velmi malým počtem odborníků, kteří mají $\mathrm{k}$ dispozici potřebné zkušenosti pro zamýšlený účel. Vývoj konečného řešení trvá přibližně 3 měsíce od doručení všech potřebných dokumentů zákazníkovi. Hardware potřebný $k$ implementaci školení o virtuální realitě se odhaduje na cenu 3000 EUR, kde 2200 EUR odpovídá stolnímu počítači s príslušnými parametry pro takový typ simulace virtuální reality17 a 800 EUR odpovídá zobrazovacímu zařízení pro virtuální realitu, jako jsou brýle atd.

\subsection{Virtuální obrábění - virtuální montáž - virtuální inspekce}

Setkat se Ize také s pojmem virtuální obrábění. Virtuální obrábění se zabývá hlavně řeznými procesy, jako je soustružení, frézování, vrtání a broušení atd. Technologie VM se používá ke studiu faktorů ovlivňujících kvalitu, dobu obrábění procesu odstraňování materiálu a relativní pohyb mezi nástrojem a obrobek.

Virtuální montáž je klíčovou součástí virtuální výroby a je definována jako použití počítačových nástrojů $k$ vytváření nebo asistenci $s$ technickými rozhodnutími souvisejícími s montáží pomocí analýzy, predikčních modelů, vizualizace a prezentace dat bez realizace produktu nebo podpůrné procesy. V montážních pracích [37] se VM používá hlavně ke zkoumání montážních procesů, mechanických a fyzických charakteristik zařízení a nástrojů, vzájemných vztahů mezi různými částmi a faktory ovlivňujících kvalitu na základě modelování a simulace. Virtuální realita může být použita pro montáž/demontáž. Může například lidský pracovník sestavit součást nebo součást? A pak Ize díl rozebrat za účelem servisu a údržby $\vee$ pozdějších fázích? Je třeba řešit i další otázky: je "složité“ nebo „snadné“" sestavit / rozebrat součást? Jak dlouho to trvá? Jak stresující je to z hlediska ergonomie? Existuje dostatek prostoru pro nástroje? [52].

Virtuální inspekce využívá technologii VM k modelování a simulaci inspekčního procesu a fyzikálních a mechanických vlastností inspekčního zařízení. Cílem je studovat inspekční metodiky, detekci kolizí [68], plán inspekcí, faktory ovlivňující přesnost inspekčního procesu atd. [40].

\subsection{Kombinace virtuální a augmentované reality}

Studie "Combining Virtual and Augmented Reality to Improve the Mechanical Assembly Training Process in Manufacturing" [59] navazuje a rozšiřuje studii „Recent Advances in Manufacturing Engineering, Proceedings of the 4th International Conference of Manufacturing Engineering, Quality and Production Systems" [69], kde byl navržen systém školení založený na virtuální realitě, který poskytuje vynikající výsledky a poskytuje příležitosti, které nejsou k dispozici při použití konvenčních metodik. Virtuální realita má však omezení, bez ohledu na to, jak realistické je virtuální prostředí, bude často existovat rozdíl oproti reálnému prostředí, v závislosti na konkrétním tréninku, který může být velký nebo malý, a když se praktikant potýká se skutečným úkolem po tréninku, tento rozdíl se projeví na jeho výkonu. Je to 
proto, že je to fenomén přenosu, a to díky skutečnosti, že dovednosti někdy nemohou být dostatečně přeneseny $z$ virtuálního prostředí do reality. $Z$ tohoto důvodu ne ve všech př́padech může virtuální realita plně nahradit konvenční metody tréninku, ale pokud to pomůže, může nahradit její důležitou část. Naproti tomu rozšířená realita je technologie, která je založena na skutečné realitě, kde jsou počítačem generované pomůcky přidávány do reálného prostředí, veškeré znalosti získané při školení lze použít přímo k provedení úkolu. Problém s rozšířenou realitou je $v$ tom, že představuje mnoho nevýhod konvenčních metodik, protože značně využívá zdroje. Pro zlepšení tréninkového procesu jako celku představuje výše uvedená studie z roku 2012 alternativní tréninkový proces, který kombinuje tyto dvě technologie, iniciuje proces s tréninkem založeným na virtuální realitě, získává všechny výhody, jako jsou nízké variabilní náklady, a finalizuje trénink s rozšířenou realitou, kde praktikant může dokončit proces učení. Z původně navržených cílů a vzhledem $k$ výsledkům je možné dojít $v$ rámci studie $k$ několika závěrům. Kombinace virtuální a rozšířené reality do jediného vzdělávacího procesu je stejně účinná jako u konvenčních metodik, navíc umožňuje efektivnější využití zdrojů a větší flexibilitu $v$ typu společností, které mohou těžit z těchto technologií, protože lépe vyhovují jejich potřebám než při použití pouze jednoho z nich. Virtuální realita a rozšírená realita mají za určitých podmínek různé aplikace, $z$ nichž jedna je $v$ některých př́padech lepší $a$ druhá $v$ jiných př́padech lepší, takže se mohou vzájemně doplňovat. Během vývoje bylo identifikováno několik aspektů, které by mohly být zahrnuty do budoucí práce na zlepšení procesu. Bylo by vhodné vyvijet další systémy VR a AR nejen proto, aby společnostem pomohly zlepšit své tréninkové procesy, ale také systémy schopné pomoci zvýšit produktivitu podnikových procesů. Pro usnadnění úkolů $v$ rámci spolupráce je možné přidat sítové funkce přes internet, kde mohou účastníci praktikovat úkoly, které vyžaduji interakci několika lidí a získat dovednosti týmové práce [59].

Ve výrobních odvětvích je již standardem používání virtuální reality a jejích metod ke zlepšení vývoje produktu, zvýšení kvality a optimalizaci finálního designu. Počítačový vizualizační a analytický software významně pomáhá snižovat rostoucí výrobní náklady a umožňuje zabránit výrobě prototypů a namáhavému testování ve výzkumných laboratořích. To urychluje vývojový projekt a zlepšuje komunikaci mezi inženýry, což umožňuje intuitivní zážitek a výměnu dat při používání srozumitelného prostředí virtuální reality. Dnešní konkurenční obchodní prostředí zvyšuje potřebu dobře vyškolených operátorů se všemi typy dovedností a ve všech odvětvích. Společnosti tlačí zařízení na své limity, zatímco procesy i automatizované systémy jsou stále komplikovanější. Předpokládaný odchod do důchodu mnoha zkušených operátorů $v$ blízké budoucnosti připraví půdu pro mladou pracovní sílu. Otázkou je, jak udržet výnosnou rychlost výroby a zajistit bezpečné a efektivní pracovní prostředí s personálem, který je v práci nový. Zde se 3D komunikace stává všudypř́tomnou, nezávislou na specializovaném softwaru a formátech a nákladově efektivní. Použití $3 D$ dat a nástrojů pomáhá urychlit komunikaci informací. Odpojení 3D dat od zatižených systémů a jejich zpřístupnění všem 
lidem v organizaci je považováno za důležitý cíl, který výrazně zlepšuje kvalitu komunikace a současně šetří čas a náklady. Díky bezpečným virtuálním prostředím je schopnost tvořit chyby a učit se $z$ chyb při provádění komplikovaných postupů a pokynů charakteristickým znakem způsobu, jak navrhnout řešení školení a vzdělávání. V rámci tohoto prístupu „učení se praxi“" může uživatel rychle identifikovat problém, klást otázky nebo získat včas instruktáž o důsledcích jeho jednání. Fotorealistické 3D modely podrobného vybavení a zařízení $v$ plném rozsahu jsou teprve začátek. Opakovaným použitím těchto dat $v$ softwarovém prostředí $v$ reálném čase může virtuální instruktor interaktivně vést studenty i přes nejpokročilejší montážní služby, kontrolní seznam údržby nebo bezpečnostní postup.

Cílem veškerého výcviku obsluhy je co nejrychleji a nejúčinněji zlepšit sadu dovedností. Realismus spojený s tréninkem virtuální reality výrazně urychluje učení a získávání dovedností. Ve skutečnosti se kombinace VR a tradičního školení osvědčila opakovaně. Schopnost zlepšit využití prostředků, opětovné použití složitých modelů a návštěva nebezpečných míst virtuálně pomocí prostředí simulovaného 3D umožňuje akumulaci času. Příkladem úspory času je vytvoření virtuálního průchodu výrobním zařízením. Realistická 3D zobrazovací technologie umožňuje prohlídku zařízení prakticky odkudkoli emulací zážitků z reálného života a vzdálené spolupráce mezi týmy. $\mathrm{Na}$ obrázku níže je uveden virtuální simulátor ropné platformy EYESIM.

Při použití pohlcujícího zobrazovacího systému $v$ plném měřítku 1: 1 je operátor proškolen o komplexní funkčnosti, která není $v$ reálném životě možná kvưli omezením nákladů a možnému riziku. Takový systém by mohl být klasifikován jako „Operator Training Simulator" (OTS), který je zásadní pro provoz výrobních zařízení a řízení neobvyklých situací. OTS umožňuje začátečníkům naučit se základy, zatímco zkušenější pracovníci jsou schopni zvládat neobvyklé nebo mimořádné situace $v$ bezpečném prostředí. Konečná kvalita modelu, simulace fyziky a řízení chování zařízení rozhoduje o tom, jak budou školení jedinci absorbovat instrukce a uchovávat si to, co se naučili při cvičení. Téměř každý stroj by mohl být rekonstruován na 3D interaktivní model $s$ reálnými a virtuálními řadiči nebo kokpity. Tyto simulátory, často nazývané Syntetické environmentální trenéry (SET), rozmazávají rozdíl mezi simulací a skutečným pracovním prostředím. SET může dramaticky zkrátit křivku učení, zlepšit dovednosti obsluhy a podpořit zvládnutí certifikace a dodržování předpisů.

Od několika let podporují technologie CG průmysl dalším velmi výkonným školicím nástrojem ve formě instrukcí pro rozšírenou realitu. ARI poskytuje počítačem generované informace o údržbě a provozu na vrcholu viditelných objektů. Průsvitné brýle promítají digitalizované modely a informace vrstvené na stávající prostředí. Operátoři mohou komunikovat s ovládacími prvky zařízení, zatímco servisní pokyny krok za krokem zvyšují uživatelský dojem. Aplikace a simulátory mohou být navrženy tak, aby se objevily na mobilních zařizeních, jako jsou elektronické tablety nebo chytré telefony, a nahrazovaly tištěný materiál vždy aktuálními pokyny pro osvědčené postupy. Tato řešení 
pomáhají transformovat zaměstnance s obecným porozuměním prostředí nebo vybavení na informovaného pracovníka pro 21 . století.

\subsection{VR a armáda}

Od počátku vývoje technologie CG (Computer Graphics) byla virtuální realita využívána $\mathrm{k}$ podpoře několika projektů obrany americké armády a jejich velitelských center. Software VR a zobrazovací zařizení dnes překračuji mnoho standardních omezení a umožňují uživatelům vzájemně komunikovat a spolupracovat $v$ digitálním světě a snižovat náklady a počet skutečných cvičení potřebných pro výcvik vojenského personálu. $V$ současnosti se počítačové aplikace většinou používají $k$ výcviku vojenských pilotů a posádek tanků $v$ bezpečném prostředí. Vojáci vstoupí do fyzického modelu vozidla obklopeného promítacími plátny, které $v$ reálném čase vytvářejí $3 \mathrm{D}$ svět kolem jejich vnímání. Nejdůležitějším prínosem vojenských sil jsou jejich zkušenosti a znalosti získané na poli $v$ boji. Vojenští funkcionáři se obávají, jak předat tyto znalosti mladému muži ve věku 18 až 24 let, a to tím nejlepším způsobem, jak zvýšit jeho dovednosti a schopnost myslet ve složitých prostředích. Během standardních vojenských cvičení není život vojáka obvykle ohrožen. To velmi ztěžuje studium jeho individuálních charakteristik chování, jeho schopnosti analyzovat hrozby, identifikovat vznikající situaci a rozhodovací proces $v$ život ohrožující situaci. VR umožňuje uspořádat nebezpečné bojové podmínky $\vee$ potenciálně bezpečném prostředí. Získaná ponaučení by bylo velmi dủležité pro odhalování podezřelého chování a jednání jednotlivců. Prostřednictvím takové virtuální zkušenosti můžeme vybrat ty nejlepší lidi pro tuto práci a připravit je na misi. Současná řešení boje $s$ VR však mají také některé hlavní nevýhody. Například, všechny simulátory jsou umístěny $v$ klimatizovaných prostředích, kde vojáci necítí teplo ani zimu, neunaví se nošením batohu s plnou hmotností při chưzi přes bažinatý terén. Možnost projít zdmi bez detekce kolizí také zpưsobuje spíš hru než seriózní trénink. Díky dnešní technologii a pokroku v počítačové grafice by se to mohlo zlepšit. Mezi četné standardní vojenské syntetické environmentální trenéry (SET) jsou každoročně $v$ armádě rozmístěny pokročilejší a složitější simulátory „první reakce“, což přináší výcvik vojsk na další úroveň. Jedno z nejsložitějších simulačních prostředí je dobře známé pod názvem DTS (Dismounted Training Soldier program). Několik výrobců nabízí systémy, které byly stážistům, spolu s jejich kolegy z týmu využívajícími vyspělou technologii a 3D zobrazovací systémy namontované na hlavě, přičemž ti jsou zcela ponořeny do virtuální reality, kde každý z jejich pohybů je kopírován optickými systémy pro snímání pohybu. S využitím nejmodernějšího softwaru a hardwarové technologie vytváŕí DTS scénáře skutečného života pro uživatele, aby se ponořili do taktických výcvikových aktivit [59]. 


\subsection{Virtuální továrna}

Pomocí virtuálních výrobních aplikací mohou společnosti navrhovat rozvržení továrny a plánovat výrobní procesy, které dramaticky zlepšují produktivitu a zkracují dobu potřebnou $k$ uvedení na trh. Toto řešení vizuálně integruje celý výrobní proces podniku, od počátečního návrhu produktu po finální výrobu, což zkracuje celkovou dobu plánování výroby, snižuje zdroje potřebné $k$ uvedení produktu na trh a výrazně zvyšuje efektivitu výrobní linky [63]. Inženýři na University of Buffalo vyvinuli virtuální tovární software známý jako VR-Fact. Tento software umožňuje uživateli procházet montážním závodem, který ještě nebyl postaven, a pohybovat se kolem těžkých kusů zařízení pouhým ukazováním a tažením myší. VR-Fact poskytuje společnostem trojrozměrnou metodu virtuálního navrhování rozsáhlých zařízení a simulaci práce v nich. Simulace zase výrobcům umožňují provádět takové věci, jako je identifikace a odvrácení potenciálních úzkých míst dlouho předtím, než se pustí do nového závodu. Mezi další funkce softwaru patří automatické generování většiny standardních strojů s využitím procesních parametrů, detekce ergonomických problémů, sledování činností prodejen a rozhraní s databázovými systémy.

Webové systémy poskytují vynikající nástroj pro sdílení virtuálních modelů nebo prostředí se vzdálenými uživateli a pro podporu spolupráce [6]. Webové systémy VR jsou tedy nákladově efektivní, protože požadovaná infrastruktura existuje téměř všude a prohlížecí software (plug-in) je volně $k$ dispozici všem. Beier dále navrhuje potenciální řešení pro standardizovaý virtuální model použití Virtual Reality Modeling Language (VRML). Zatímco HTML, HyperText Markup Language, je současným standardem pro tvorbu domovských stránek, VRML podporuje distribuci trojrozměrných modelů přes internet. Tyto modely jsou založeny na polygonální reprezentaci a mohou být animovány, mohou zahrnovat funkčnost a dynamické chování a mohou být interaktivně kontrolovány uživatelem.

\subsection{Aplikace virtuální reality ve výrobě a zvuková simulace}

Text „Virtual Reality in Manufacturing“ [63] představuje koncept a aplikace virtuální reality ve výrobě. Výhody použití VR ve výrobě byly zdůrazněny a byly diskutovány některé potenciální oblasti aplikací VR ve výrobě. VRML, který byl vyvinut pro internet a WWW, $v$ současné době představuje nejdůležitěší způsob doručování trojrozměrných objektů na obrazovku libovolného uživatele. Umožňuje prezentovat trojrozměrné objekty a simulovat jejich chování. Spousta výrobních aplikací může těžit z funkcí VRML, pokud jde o prezentaci nových modelů, volitelných návrhů a různých objektů $s$ různou funkčností [48]. Je důležité si uvědomit, že VR není pouze pro účely vizualizace, nýbrž nabízí zlepšené metody interakce a vizualizace, kde může být použit $v$ reálných technických problémech.

Velmi mě zaujala otázka hluku ve vazbě na možnosti simulace. Přestože je otázka hluku ve výrobě široce diskutována z právních a zdravotních hledisek, stále neexistuje žádná komplexní metoda, která by ji simulovala a 
analyzovala. V článku „Noise investigation in manufacturing systems: An acoustic simulation and virtual reality enhanced method" [3] je navržen nový koncept pro zkoumání hladiny hluku. Jedná se o simulační metodu a implementaci virtuální reality $(\mathrm{VR})$. Akustická měření $v$ reálném závodě poskytují validační data pro realistickou simulaci. Reprezentace výsledků simulace ve virtuálním prostředí je dále vizualizována $v$ automatickém virtuálním prostředí jeskyně (CAVE). Aby bylo možné určit vlivy hluku, je akustická simulace implementována $v$ mnoha různých oblastech. Simulační metody jsou stručně rozděleny na numerické simulace a geometrické metody. Numerické metody jsou založeny na řešení vlnových rovnic, jako jsou metody konečných prvků (FEM), metody hraničních prvků (BEM) a časové domény konečných rozdílů (FDTD). Geometrické metody nám zjednodušuji procesy šíření zvuku. Jedná se například o metodu zdroje obrazu, trasování paprsků a metody trasování paprsků. Ve srovnání s numerickými metodami geometrické metody výrazně zlepšují výpočetní výkon zvukové simulace, avšak za cenu zjednodušení předpokladů. Přehled a srovnání těchto metod je také uvedeno ve stávající literatuře [60] [66] [20] [64]. Vzhledem ke složitosti výpočtu nejsou zavedené vinové a geometrické metody pro velké geometrické modely praktické a efektivní. Byl vyvinut vylepšený geometrický přistup nazvaný „Sledování fononu“ [20] [8], který je implementován v uvedeném článku. Tato metoda je inspirována metodou detekce fotonů, která bere $v$ úvahu světelné částice zvané fotony a simuluje fotorealistický obraz. Analogicky $k$ vidění světla jako částic nazývaných fotony, zdroje zvuku emitující zvukové částice se nazývají fonony. Sledování fononu je metoda geometrické akustiky, která jako vstup potřebuje geometrická data. Generují se 3D modely továren, zařízení a různých strojů, které jsou vstupem do integrovaného scénického grafu. Sledováním tlaku v různých frekvenčních pásmech a použitím Diracova impulsu jako zdroje zvuku tento výpočet poskytuje impulzní odezvu místnosti. Tento simulační proces je třeba opakovat, pouze pokud se změní zdroje zvuku a pozice posluchače. $V$ uvedeném článku [3] je simulace použita pro výpočet hladiny akustického tlaku $v$ libovolných pozicích posluchače. Simulace a vizualizace jsou pak implementovány ve virtuálním prostředí.

Zvuková simulace, metoda sledování fononu, vyžaduje několik nastavení vstupních parametrů. Protože se jedná o geometrický prístup, algoritmus potřebuje geometrický model místnosti a objekty uvnitř. Každému povrchu je přiřazen jeden materiál se specifickými absorpčními vlastnostmi. Absorpční koeficienty materiálu jsou obvykle převzaty z tabulek koeficientů. Jsou uvedeny parametry, které jsou nezbytné pro simulaci: trojosý scénářový graf s označeným povrchovým materiálem, absorpční koeficienty / funkce pro různé materiály, poloha jednoho nebo více zvukových zdrojů, distribuce zvukové energie a emise zvukových zdrojů, počet fononů do ke sledování, počet odrazů, které mají být sledovány, prahová energie fononů na konci simulace. Pro tento zdroj zvuku je nutná poloha a akustický tlak ve vzdálenosti $1 \mathrm{~m}$. Lepších výsledků se dosáhne poskytnutím bud' anechoického signálu zdroje zvuku, tj. simulovaného stroje, nebo úrovně akustického tlaku několika frekvencí. Dále může uživatel zadat libovolný počet posluchačů, od kterých je 
potřeba pouze pozice. Počet fononů je definován uživatelem. Velký počet fononů poskytuje simulační data s vyššími detaily pro vizualizaci a auralizaci. Lidské ucho však není schopné lokalizovat původ zdroje zvuku. Proto menší počet fononů postačuje pro auralizaci a efektivní i pro simulaci. Rychlost zvuku ve vzduchu je považována za konstantní hodnotu $314 \mathrm{~m} / \mathrm{s}$. Více podrobností o nastavení simulace Ize nalézt $v$ disertační práci „Acoustic Simulation and Visualization Algorithms" [20].

Zvuková simulace je nejprve implementována pomocí prohlížeče VRML „Instant Player" a "Cortona3D Viewer", který uživateli umožňuje procházet a manipulovat $s$ grafem scény VRML $v$ pracovním prostoru založeném na ploše. Po načtení modelu na každou adresu URL do aplikace prohlížeče může uživatel prozkoumat místnost, která umístí zdroj zvuku a spustí akustickou simulaci. 3D rozhraní pomáhá uživatelům najít zdroj zvuku. Po dokončení simulace se software přepne na krok sběru fononů. Uživatelé mohou zkoumat šíření zvuku uvnitř místnosti sledováním animovaných fononových cest. Rychlost přehrávání Ize nastavit pomocí tlačítek „++“ a „-" a aktuální krok simulace Ize vybrat posuvníkem. A jeden nebo více posluchačů jsou umístěni $v$ místnosti podle provozních pozic. Geometrii posluchače Ize prizizpůsobit. Poté Ize provést krok sběru fononů. Tato aplikace je dále implementována $v$ CAVE. Simulační server otevře port HTTP pro moduly COVISE a získá zpětnou vazbu od COVISE. Dva nezbytné moduly COVISE jsou moduly „VRML renderer“ a „VR“. První umožňuje VRML vizualizaci grafu scény $\vee$ CAVE a druhý poskytuje základní interakční funkce, jako je navigace a sledování uživatelů.

Byt' je výše zmíněné velmi zajímavé, je nutné podotknout, že simulace podporuje umístění pouze jednoho zdroje zvuku. Výrobní haly obvykle obsahují několik strojů běžících současně. Proto se mi zdá jako efektivní vývoj zahrnující více zdrojů zvuku. Kromě toho je změna akustických vlastností místnosti velmi těžkopádná, protože zahrnuje změnu původního modelu místnosti. Toto musí být rozšiřeno, aby se zajistilo interaktivní nastavení absorpčního koeficientu, např. pro simulaci různých stavebních materiálů [3].

\subsection{Vzdělávání ve virtuální realitě a stárnutí populace}

To, co je z mého pohledu často opomíjeno, tedy především ve vztahu ke školení zaměstnanců, je jejich věk. Zde se mi jeví jako obzory velmi rozšiřující studie „A virtual training system for aging employees in machine operation" [43]. Tento článek představuje virtuální tréninkový systém pro provoz stroje, který řeší stárnoucí pracovní sílu. Zaměření na potřeby a schopnosti stárnoucích zaměstnanců je nevyhnutelné pro řešení probíhajících demografických změn a zachování konkurenceschopnosti. Navrhovaný systém se skládá z virtuální reprezentace stroje a ovládacího panelu na samostatném tabletovém počítači. Příspěvek popisuje didaktický přístup, způsoby interakce a způsob, jakým Ize systém přizpůsobit schopnostem jeho uživatelů. Ukázkový scénář popisuje použití konceptu $v$ prototypu. Mnoho 
vzdělávacích systémů použíaá technologii virtuální reality. Klíčovou motivací jsou úspory nákladů, protože operátoři mohou být vyškoleni bez zapojení fyzického vybavení nebo trenéra. Př́kladem použití jsou náběhy produktů $v$ automobilovém průmyslu, kde výrobní školení může začít před výrobou prvních součástí [56]. Virtuální výcvik navíc umožňuje trénovat, aniž by byl vystaven inherentním rizikům úkolu [41], nebo trénovat, simulovat a vyhodnocovat postupy údržby za různých vlivů prostředí [11]. Druhým směrem výzkumu jsou systémy, které podporují pracovníky při montážních úkolech. Tyto systémy využívají rozšířenou realitu a zobrazují grafické pokyny, které ukazují pracovní kroky. Takové systémy používají jako výstupní zařízení displeje namontované na hlavě [75] nebo obrazovky [9] nebo promítají pokyny na povrch pracovní desky [67]. Díky nepřetržité asistenci na místě jsou tyto systémy vhodné pro podporu pracovníků se zdravotním postižením [26] nebo pro komplexní montážní procesy s četnými variantami produktů [44].

Adaptivita popisuje schopnost systému přizpůsobit jeho vlastnosti konkrétnímu uživateli a jeho situaci [14]. Je to důležitý prvek vzdělávacích systémů, protože zaměstnanci mají různé dovednosti a schopnosti. Individuální úroveň odborných znalostí je jedním z aspektů, které mohou vést k přizpůsobení. Například virtuální simulátor soustruhu zvyšuje obtížnost úkolu po úspěšných pokusech $s$ nižší obtížností [41]. $V$ automobilovém simulátoru montáže musí zkušení uživatelé zapamatovat potřebné nástroje pro každý krok, zatímco tyto informace jsou poskytovány začátečníkưm. Ostatní systémy se během používání přizpůsobují, například na základě měřeného výkonu. Systém může snižit množství pomoci, když má uživatel dobré výsledky [39]. Další možnosti pro dynamickou adaptaci jsou navrženy v rámci kontextově orientovaného počítače [23]. Přizpůsobení roli a poloze uživatele by mohlo poskytnout zaměstnanci podrobné údaje o procesu, zatímco vedoucí obdrží klíčové ukazatele výkonu [30].

Demografická změna je náročná pro oblast výroby. Nejstarší věková skupina (55-64 let) vzroste v letech 2010 až 2030 o přibližně 16,2\% (9,9 milionu), zatímco u ostatních věkových skupin se očekává pokles [10]. Tento trend je patrný i na pracovní síle. $V$ př́padové studii bylo zaznamenáno zvýšení průměrného věku pracovní síly $v$ automobilovém výrobním závodě ze 40,3 na 47,5 roku během 8 let (2002-2010) [65]. Tyto změny jsou zásadní, protože věk je uváděn jako třetí nejdůležitější faktor přispívající $k$ výkonu práce jednotlivce [10]. Věk je dále spojen s výskytem postižení, jakož i se snížením fyziologických a kognitivních schopností [35].

Podpora manuálních úkolů je předmětem výzkumu, protože toto nastavení nabízí kontrolovatelné prostředí pro kvantitativní vyhodnocení. Rostoucí automatizace však sníží množství manuální práce [16]. Výrobní pracovníci budou zodpovědní za složitější úkoly, jako je provoz stroje. Provoz ovládacího panelu stroje vyžaduje více vizuálních zdrojů a počítačové znalosti, než motorické dovednosti, které jsou nezbytné při ručních úlohách. Dále vyžaduje častý přesun pozornosti mezi ovládacím panelem a strojem, napríílad při 
provádění úkolů údržby, které vyžadují fyzickou manipulaci. Výzkum zaměřený na provoz stroje pomocí virtuálního výcvikového systému je vzácný. Stárnoucí pracovní síla je realitou, kterou musí systémy školení řešit. Jen malé procento výzkumů však zvažuje individuální schopnosti stárnoucích zaměstnanců. Vysoká věrnost a vizuální složitost mnoha systémů [29] může přetížit snížené vizuální vnímání starších osob. Kromě toho vzdělávací systémy [44] [26] nejsou integrovány do strukturovaného vyučovacího procesu, který je nezbytný pro uspokojení stárnutí zaměstnanců. Studie „A virtual training system for aging employees in machine operation" [43] navrhla virtuální systém školení pro provoz stroje, který Ize přizpůsobit schopnostem stárnoucích zaměstnancủ. Systém se zaměřuje na stárnoucí operátory. Lekce mohou být opakovány s různými obtižemi, dokud uživatel nezvládne úkol. Chráněné prostředí odstraňuje rozptýlení, které by bylo prítomno $v$ jiných vzdělávacích prostředích. Charakteristiky školicího systému mohou být vhodné i pro další zranitelné skupiny zaměstnanců, jako jsou nekvalifikovaní nebo nízko vzdělaní pracovníci. Vylepšené systémy školení jsou prospěšné pro zaměstnance $\mathrm{i}$ zaměstnavatele. Zaměstnanci absolvují přizpůsobené školení, které jim umožní snadněji získat nové dovednosti, a tím otevírají další pracovní príležitosti. Zaměstnavatelé těží, protože jsou schopni integrovat více zaměstnanců do své pracovní síly. Systém by mohl získat možnosti pro adaptaci $v$ reálném čase. Napríklad detekce stresu by mohla automaticky snižit rychlost animací, zvýšit podrobnosti pokynů nebo zavolat další pomoc (např. osobního trenéra). Stres Ize detekovat měřením $v$ reálném čase, například pomocí sledování očí nebo měření srdeční frekvence. Kromě toho by systém mohl vyzvat uživatele, aby opakoval lekci, pokud by byly zjištěny chyby.

\subsection{Praktické sledování využití virtuální reality pro školení v komparaci s konvenčním vzděláváním/zaškolováním}

Studie „Assessment of virtual reality-based manufacturing assembly training system“ [1] ukazuje, že účastníci trénovaní VR se dopustili méně chyb a ve skutečném sestavení produktu si vzali méně času ve srovnání s účastníkem z tradiční nebo základní skupiny školení. Vědci zmiňují několik výhod VR pro ruční montážní výcvik, jako jsou modely $C A D$, které Ize přenést do virtuálního prostředí, které dává pocit reálného prostředí místo vytváření fyzických částí, což šetří čas; uživatel si může $v$ prostředí VR procvičovat tolik času, kolik se mu líbí, aniž by se musel obávat selhání komponenty; je menší závislost na fyzickém trenérovi, protože žáci mohou vést digitální instrukce; a nehrozí žádné riziko spojené $s$ výcvikem montáže jemných součástí nebo součástí [61] [7] [53] [42]. Obdobné výhody ve výše uvedené studii potvrdili i Abidi, AlAhmari, Ahmad et al. [1]. Byly provedeny uživatelské studie, jejichž cílem bylo otestovat účinnost a funkčnost virtuálního školicího systému. Jmenovaná práce představuje tréninkový systém založený na VR $\mathrm{S}$ cílem usnadnit a zrealističtit trénink montáže pomocí multimodálního vstupu a výstupu. Účinek multimodálního mechanismu zpětné vazby na výkon uživatelů byl úspěšně vyhodnocen. Na základě pozorování Ize říci, že interakční zařízení jsou 
klíčem $\mathrm{k}$ dosažení vysoké úrovně ponoření, protože umožňují přirozenější interakci se systémem, a tudíž mohou být dovednosti přenášeny vhodněji. $\mathrm{Na}$ základě uživatelské studie VMASS byla učiněna řada závěrů. Účastníci vyškolení VMASS se ve srovnání s účastníkem z tradiční nebo základní skupiny školení dopustili méně chyb a zabrali méně času při skutečné montáži produktu. Skupina založená na VR však ve srovnání se základní skupinou trvá ve výcviku mnohem více času. $V$ případě složitějších produktů skupiny osob získávající zpětnou vazbu udělaly méně chyb ve skutečné montáži ve srovnání se skupinou bez zpětné vazby. $V$ prrípadě jednoduché montáže nedošlo $k$ výraznému rozdílu ve výkonu účastníků $z$ různých výcvikových skupin. Proto Ize říci, že školení na bázi VR je účinnější při montáži komplexních produktů. VR poskytuje platformu pro "učení se praxi“ místo učení se viděním, poslechem nebo pozorováním. S rostoucí složitostí produktu se zvyšuje čas na provedení skutečné montáže a zvyšuje se počet chyb, ale skupina založená na VR stále fungovala lépe než základní tréninková skupina. Semi-imersní virtuální prostředí poskytuje uživateli měřítko 1: 1 produktu $v$ digitálním prostředí, což zvyšuje pocit př́tomnosti ve virtuálním prostředí. $V$ některých případech mohou být systémy založené na VR nákladnější a časově náročnější, poskytují však pro výuku a školení prostředí bez rizika a zranění [1]. Omezení studie spočívá z mého pohledu v tom, že populaci podrobenou empirickým hodnocením tvořili mladí studenti a zaměstnanci vysokých škol, což může ovlivnit zobecnění závěrů studie. Navíc ve virtuálním prostředí nebyla přitomna silová zpětná vazba a fyzikální vlastnosti. Budoucí práce by se mohla $z$ mého pohledu zaměřit na vyhodnocení dopadu, který umožní účastníkům získat více času během základního výcviku namísto toho, aby jim bylo umožněno včasné dokončení, a to včetně posouzení systému s fyzickými vlastnostmi a silou zpětné vazby aplikované na digitální prostředí. Kromě toho Ize posoudit vliv úrovně zázemí a odborné znalosti účastníků na výkon školení v montáži.

Virtuální realita nachází své uplatnění také v chemickém průmyslu. Chemický průmysl často vyžaduje, aby lidé pracovali $v$ nebezpečném prostředí $a$ obsluhovali komplikovaná zařízení, která často omezují typ školení prováděného na místě. Každodenní práce provozovatelů chemických závodů je stále náročnější $v$ důsledku rostoucí složitosti zařízení a rostoucích požadavků na bezpečnost zařízení, výrobní kapacitu, kvalitu produktu a efektivitu nákladů. Důležitost navrhování systémů a prostředí, které jsou co nejbezpečnější pro vzdělávání a odbornou přípravu personálu, je pro průmysl chemických procesů zásadní. Virtuální realita nabízí potenciál vystavit personál nebezpečným situacím bezpečným, vysoce vizuálním a interaktivním způsobem. Této problematice se věnuje např́klad disertační práce „Improving Chemical Plant Safety Training Using Virtual Reality“ [54]. Pro tento výzkum bylyvyvinuty čtyři tréninková prostředí pro virtuální realitu stolního počítače, která zdưraznila problémy související $s$ dynamickou simulací chemických procesů a bezpečností továren. Výcvikový systém čerpadel je prostředí virtuální reality, které bylo vytvořeno pomocí virtuálního motoru SAFE-VR, aby školilo personál $k$ ovládání dvou odstředivých 
čerpadel. Cvičení zaměřené na virtuální sledování spotů se zaměřuje na zlepšení povědomí uživatelů o nebezpečí elektrické a pracovní hygieny. Virtuální kotelna je složité a vysoce detailní virtuální tréninkové prostředí, které se vyznačuje svou flexibilitou a dynamickou simulací chemického procesu výroby páry $v$ reálném čase. Experiment virtuálního zaplavení a absorpce plynu byl založen na vysokoškolském laboratorním experimentu pro magisterské studium chemického inženýrství na University of Nottingham se zaměřením primárně na školení a otázky bezpečnosti studentů používajících zařízení.

\subsection{Virtual human resource development}

To, že se využití virtuální reality stává velmi významnou, efektivní a platnou součástí rízení lidských zdrojů je nezpochybnitelné. Pro jednotlivce je jednou z kritických oblastí, na které se virtual human resource development (VHRD) zaměřuje, profesní rozvoj. Intervence VR mohou pomoci při rozvoji lidských zdrojů $v$ různých fázích od vstupu do výstupu. Nástroje VR usnadňují nástup nových zaměstnanců do pracovního procesu, protože se plynule dozvědí o různých otázkách své nové role tím, že integrují postoje, znalosti, dovednosti a chování potřebné pro efektivní fungování. Virtuální prohlídky pracovního prostředí umožňují novým zaměstnancưm aklimatizovat se před zahájením práce. Zaměstnanci mohou provádět simulace interaktivních úkolů a ukázky produktů $z$ první ruky $v$ simulacích VR. KFC, hlavní řetězec rychlého občerstvení, přišel s VR hrou pro nástup nových kuchařů [45]. Pro opravdový a ilustrativní pocit poskytl herní program VR postupné pokyny k prípravě podpisových pokrmů. VR se používá pro navrhování a provádění orientačních programů pro nové zaměstnance. Honeygrow, restaurační řetězec, ve svém orientačním programu představoval 3D grafiku, interaktivní učební situace a mini-hry pro školení a orientaci svých zaměstnanců [17].

Nedostatek príležitostí k rozvoji je jedním z hlavních důvodů opotřebení. Školení umožňující VR může působit jako všelék na potřeby rozvoje zaměstnanců a může vést $k$ výhodám, jako je zvýšení efektivity, štastnější zaměstnanci, vyšší angažovanost a vyšší retence. Velký počet organizací využívá potenciál VR v podnikovém vzdělávání a učení. Společnosti využívají VR k organizaci a asistenci při zadávání firemních školení mimo pracoviště.

Vysoký stres a nebezpečné práce, jako je hašení požáru, občas vystavují zaměstnance různým nebezpečným scénářùm. $V$ takových pozicích umožňuje předchozí expozice prostřednictvím VR hladký přechod a zvyšuje efektivitu skutečné práce [50]. Například Boeing, hlavní letecká společnost, přišla s myšlenkou Immersive Development Center, aby vyškolila piloty pomocí hyperreálných simulací VR [9].

Pro studenty medicíny vyvinula jedna americká univerzita v Kalifornii v San Franciscu školicí program, který může transformací porozumět anatomii těla pomocí VR [4]. Dokonce i pro zkušené a odborné chirurgy nabízí výcvik VR působivé a realistické situace, kdy mohou lékaři praktikovat na virtuálních a hypotetických prípadech. Tito chirurgové mohou stavět odborné znalosti o 
podmínkách, které jsou vzácné, a to tak, že pracují na simulacích ve 3D, které umožňují prohlížení uvnitř srdce, což pomáhá hlouběji a přesněji porozumět problému [21]. Tento typ VR asistovaného školení přináší posun $V$ paradigmatu toho, jak se trénuje výcvik další generace lékařư spolu se současnou generací.

V NASA se VR používá $k$ výcviku astronautů $v$ aspektech, jako je kosmická plavba a učení se o činech, jako je nahrazení vadné části kosmické lodi. Použitím VR během tréninku mohou astronauti snížit chyby na skutečné kosmické lodi [71]. Logistická společnost UPS přišla s mezinárodním školicím zařízením využívajícím VR, aby naučila základy řízení dodávkových vozidel a doručování balíků pomocí praktického prístupu se simulovanými dodávkami a vyzvedávacími servery [46].

Výzkum na University of Texas $v$ Dallasu ukazuje, že nový vzdělávací program VR pomáhá dětem $s$ autismem zlepšit jejich sociální kognitivní dovednosti. Bylo zjištěno, že většina dětí s vysoce fungujícím autismem má nadprůměrné intelektuální schopnosti. Navzdory nadprůměrným mentálním schopnostem však často čelí sociálním potížím, protože čelí problémům $\mathrm{s}$ regulací emocí a myšlenek během sociálních interakcí a komunikací, což vede k sociální izolaci a nízké sebevědomí. Účastníci studie byli školeni pomocí VR tréninkového řešení, které je zapojilo do rozhodnutí založeného na strategickém cvičení během společenského setkání. Výsledky ukázaly významné zlepšení v jejich schopnosti analogického uvažování při porovnání sociálních scén [24]. Existence konceptu tréninkové intervence založené na VR, která využívá interaktivní a vizuálně stimulující přístup, je užitečná pro jednotlivce se speciálními potřebami. Intervenční zásah VR nabízí dynamickou platformu schopnou simulovat bezpočet sociálních scénářů pro praktikování smysluplných sociálních výměn $v$ bezpečném a neohrožujícím prostředí. Řešení školení založené na VR poskytuje životaschopnou platformu pro trénování sociálních dovedností na odlehlých místech, těm, kteří maji potíže s místním přístupem $\mathrm{k}$ léčbě nebo školení.

E-maily, Skype hovory nebo jiné typy videokonferenčních hovorů někdy nestačí v situacích, kdy je nutná prímá osobní komunikace a interakce. Spojení zprostředkovaná prostřednictvím VR šetří čas a náklady na cestování, protože umožňují virtuální interakce mezi zaměstnanci a klienty po celém světě. VR vede $k$ pocitu sounáležitosti $s$ jinou osobou, kterou nelze zažít jinak, pokud neexistuje skutečné osobní setkání. Společnost Time Inc. představila LIFE VR, který uživatelům umožňuje zažít pohlcující vyprávění prostřednictvím 360stupňového videa.

Existují VR řešení pro budování týmů, která umožňují zapojení více hráčů. Budování týmů pro více hráčủ zasahuje zcela novou úroveň, přičemž do cvičení je zapojeno mnoho hráčů. Multiplayer VR zkušenosti umožňují skupinám spolupracovat současně na překonání obtížných výzev. Simulace multiplayerové VR pro budování týmu vede celý tým do neznámé říše a umožňuje členům týmu přicházet $s$ kreativními nápady na řešení problémů tím, že umožňuje členům týmu komunikovat jako tým. Cvičení pro vytváření 
týmů VR pro více hráčů umožňuji supervizorům shromažd’ovat data pro zpětnou vazbu.

Produkty jako Tilt Brush od společnosti Google Ize použít k budování kompetencí, jako jsou - vedení, komunikace, řešení problémů a prostorové uvažování. Tato aplikace VR umožňuje uživatelům kreslit ve 3 rozměrech a je složitější. Činnost zaměřená na budování týmu pomocí Tilt Brush zahrnuje učení a pomáhá přizpůsobit se osobním preferencím a stylům komunikace [32].

\section{$3 \quad$ Metodika}

Tento text je výsledkem rešeršní činnosti jakožto výstup studia v prvním ročníku doktorského studijního programu P2301 - Prưmyslové inženýrství a management. Při studiu bylo využíváno především zahraničních odborných recenzovaných časopisů. Rešerše byla realizována s ohledem na vlastní téma disertační práce jako dílčí podklad pro další rozpracování a implementaci v rámci vlastního výzkumného záměru.

\section{Závěr}

Z prostudované dostupné literatury vnímám jako realizovatelné zacílení na malé a střední podniky působící $v$ oblasti výroby $v$ rámci Plzeňského kraje. Jako smysluplné se mi jeví využití virtuální reality pro zaškolení ve smyslu montáže, ale i bezpečnosti, stejně tak vidím jako přínosné reflexi stárnoucí populace ve vazbě na adaptabilní úpravu zaškolovacího programu reflektujícího tempo zvládání. Jako vhodné vidím sledování a porovnání stávajícího stavu a stavu po implementaci či testování využití VR s cílem získání potřebných dovedností, a to ve smyslu časového, ekonomického, ale i ve smyslu udržitelnosti ve vazbě na fluktuaci zaměstnanců, nebot' i nezvládnutí práce přináší nespokojenost pocitovanou na straně zaměstnance. Jako jednu $z$ vhodných oblastí pro realizaci studie vnímám automotive, je otázkou, zda dělat komparaci $v$ rámci stejného segmentu, nebo se zaměřit na tři různé segmenty, $\mathrm{k}$ čemuž se přikláním spíše.

\section{Poděkování}

Tento článek byl vytvořen za podpory interního grantu Západočeské univerzity číslo projektu je SGS-2018-031 s názvem Optimalizace parametrů udržitelného výrobního systému. 


\section{Použitá literatura}

[1] Abidi, M. H., Al-Ahmari, A., Ahmad, A. et al. 2019. Assessment of virtual reality-based manufacturing assembly training system. Int $J$ Adv Manuf Technol 105, 3743-3759.

[2] Allen, R. B. 1997. Mental models and user models. In Helander, M, Landauer, T. K., Prabhu, P. (Eds.), Handbook of human computer interaction (2nd ed., pp. 49-63). Amsterdam: Elsevier.

[3] Aurich, J. C., Yang, X., Schröder, S., Hering-Bertram, M., Biedert, T., Hagen, H., Hamann, B. 2012. Noise investigation in manufacturing systems: An acoustic simulation and virtual reality enhanced method. CIRP Journal of Manufacturing Science and Technology, 5(4) 337-347.

[4] Baker, M. 2018. How VR is Revolutionizing the Way Future Doctors are Learning about Our Bodies. In: UCSF [online]. [cit. 2020-06-08]. Dostupné z: https://www.ucsf.edu/news/2017/09/408301/how-vr-revolutionizing-wayfuture-doctors-are-learning-about-our-bodies

[5] Bayliss, G. M., Bower, A., Taylor, R. I., Willis, P. J. 1994. Virtual Manufacturing, Presented at CSG 94-Set Theoretic Modelling Techniques and Applications, Winchester, UK, pp. 13-14.

[6] Beier, K. P. 2000. Web-Based Virtual Reality in Design and Manufacturing Applications. COMPIT'2000, 1st International EuroConference on Computer Applications and Information Technology in the Maritime Industries, Potsdam, Germany, March 29 - April 4.

[7] Berg, L. P., Vance, J. M. 2017. Industry use of virtual reality in product design and manufacturing: a survey. Virtual Reality, 21(1):1-17.

[8] Bertram, M. et al. 2005. Phonon Tracing for Auralization and Visualization of Sound. Proceedings of IEEE Visualization (VIS'05), 151-158.

[9] Boeing. 2017. Flying Virtually Solo: Aviation Avatars the Wave of the Future? Boeing [online]. [cit. 2020-06-04]. Dostupné z: https://www.boeing.com/features/2017/07/virtual-copilot-07-17.page

[10] Boenzi, F., Mossa, G., Mummolo, G., Romano, V. A. 2015. Workforce aging in production systems: Modeling and performance evaluation, Procedia Engineering, 100: 1108-1115.

[11] Borba, E. Z., Cabral, M., Montes, A, Belloc, O., Zuffo, M. 2016. Immersive and interactive procedure training simulator for high risk power line maintenance. ACM SIGGRAPH 2016 VR Village, 1.

[12] Brey, P. 1999. The Ethics of Representation and Action in Virtual Reality. Ethics and Information Technology 1(1): 5-14.

[13] Brey, P. 2008. Virtual Reality and Computer Simulation In Himma, K., Tavani, H., Handbook of Information and Computer Ethics, John Wiley \& Sons.

[14] Bruder, C., Blessing, L., Wandke, H. 2014. Adaptive training interfaces for less-experienced elderly users of electronic devices. Behaviour \& Information Technology, 33(1): 4-15. 
[15] Burke, R. 2001. Success or Failure: Human Factors in Implementing New Systems. Los Angeles, University of Judaism.

[16] Campatelli, G., Richter, A., Stocker, A. 2016. Participative knowledge management to empower manufacturing workers. International Journal of Knowledge Management, 12(4): 37-50.

[17] Clabaugh, J. 2017. Fast-Casual Honeygrow Expands, Uses VR to Train Employees. AP News [online]. [cit. 2020-06-04]. Dostupné z: https://apnews.com/ba4db4a433f546e1aa01854675b11593

[18] Costello, P. 1997. Health and Safety Issues associated with Virtual Reality-A Review of Current Literature. Loughborough, Loughborough University.

[19] Dávideková, M., Mjartan, M., Gregus, M. 2017. Implementing Virtual Reality into Employee Education in Production Sector of Automotive Industry: Creating Worker Training for Assembling Car Dashboard in Virtual Reality. AD ALTA: Journal of Interdisciplinary Research, 7: 185-190.

[20] Deines, E. 2008. Acoustic Simulation and Visualization Algorithms, PhD thesis, University of Kaiserslautern.

[21] DeMarinis, T., Calligaro, L., Harr, C., Mariani, J. 2018. Real Learning in a Virtual World. In: Deloitte Consulting LLP [online]. [cit. 2020-06-08].

Dostupné z: https://www2.deloitte.com/content/dam/insights/us/articles/4683 reallearning-virtual-world/4683 real-learning-in-a-virtual-world.pdf

[22] Dépincé, P., Chablat, D. 2004. Virtual Manufacturing Tools for improving Design and Production. Nantes: Université de Nantes.

[23] Dey, A. K. 2001. Understanding and using context. Personal and Ubiquitous Computing, 5(1): 4-7.

[24] Didehbani, N., Allen, T., Kandalaft, M., Krawczyk, D., Chapman, S.. 2016. Virtual Reality Social Cognition Training for Children with High Functioning Autism. Computers in Human Behavior, 62: 703-711.

[25] Filigenzi, M. T., Orr, T. J., Ruff, T. M. 2000. Virtual Reality for Mine Safety Training, Applied Occupational and Environmental Hygiene, 15(6): 465-469.

[26] Funk, M., Dingler, T., Cooper, J., Schmidt, A. 2015. Stop helping me - i'm bored! Adjunct Proceedings of the 2015 ACM International Joint Conference on Pervasive and Ubiquitous Computing and Proceedings, 1269-1273.

[27] Gee, J. 2003. What Video Games Have to Teach Us About Learning and Literacy. ACM Computers in Entertainment, 1(1): 1-4.

[28] Gee, J. 2007. Good Video Games and Good Learning. Madison, University of Wisconsin-Madison.

[29] Gorecky, D., Schmitt, M., Loskyll, M., Zuhlke, D. 2014. Human-machineinteraction in the industry 4.0 era. 12th IEEE International Conference on Industrial Informatics (INDIN), 289-294.

[30] Gröger, C., Stach, C. 2014. The mobile manufacturing dashboard, IEEE International Conference on Pervasive Computing and Communications workshops (PerCom workshops). 
[31] Hamid, N. S. S., Aziz, F. A., Azizi, A. 2014. Virtual reality applications in manufacturing system. Science and Information Conference, London: 10341037.

[32] Hernandez-Pozas, O., Carreon-Flores, H. 2019. Teaching International Business Using Virtual Reality. Journal of Teaching in International Business 30(2): 196-212.

[33] Hocine, N., Gouaïch, A. 2011. Therapeutic Games Difficulty Adaptation: An Approach Based on Players Ability and Motivation. Louisville, KY, IEEE.

[34] Hoffman, G., Breazeal, C. 2007. Effects of anticipatory action on humanrobot teamwork efficiency, fluency, and perception of team. Proceeding ACM/IEEE Int. Conf. Human-robot Interact. - HRI '07: 1-8.

[35] Chen, K., Chan, A. 2011. A review of technology acceptance by older adults. Gerontechnology, 10(1): 1-12.

[36] Iwata K., Onosato M., Teramoto K., Osaki S. A. 1995. Modeling and Simulation Architecture for Virtual Manufacturing System, Annals CIRP, 44: 399-402.

[37] Jayaram, S., Connacher, H., Lyons, K. 1997. Virtual Assembly using virtual reality techniques, Comp. Aided Des. 29: 557-584.

[38] Kalawsky, R. S. 1996. Exploiting Virtual Reality Techniques in Education and Training: Technological Issues. SIMA Report Series ISSN 1356-5370.

[39] Korn, O., Funk, M., Abele, S., Hörz, T., Schmidt, A. 2014. Context-aware assistive systems at the workplace. analyzing the effects of projection and gamification. PETRA '14 Proceedings of the 7th International Conference on PErvasive Technologies Related to Assistive Environments, 1-8.

[40] Lee, W. B., Cheung, C. F., Li, J. G. 2001. Applications of virtual manufacturing in materials processing, J. Mater. Process. Technol. 113: 416-423.

[41] Liang, X., Kato, H., Higuchi, S., Okawa, K. 2012. High efficiency skill training of lathe boring operations by a virtual reality environment. IEEE International Conference on Mechatronics and Automation (ICMA), 285-290.

[42] Lin, Y., Yu, S., Zheng, P., Qiu, L., Wang, Y., Xu, X. 2017. VR-based product personalization process for smart products. Procedia Manuf, 11:1568-1576.

[43] Loch, F., Vogel-Heuser, B. 2017. A virtual training system for aging employees in machine operation. IEEE 15th International Conference on Industrial Informatics (INDIN), Emden, 279-284.

[44] Loch, F., Quint, F., Brishtel, I. 2016. Comparing video and augmented reality assistance in manual assembly. 12th International Conference on Intelligent Environments (IE), 147-150.

[45] Mascarenhas, H. 2017. KFC's Bizarre New VR Training Game Teaches You to Cook Chicken 'The Hard Way' in an Escape Room. Internationa Business Times [online]. [cit. 2020-06-04]. Dostupné z: https://www.ibtimes.co.uk/kfcsbizarre-new-vr-training-game-teaches-you-cook-chicken-hard-way-escape-room$\underline{1636519}$. 
[46] Matney, L. 2017. UPS is Developing Virtual Reality Tech to Train its Drivers. In TechCrunch. [online]. [cit. 2020-06-08]. Dostupné z:

https://techcrunch.com/2017/08/15/ups-is-developing-virtual-reality-tech-totrain-its-drivers/

[47] Matsas, E., Vosniakos, G. 2017. Design of a virtual reality training system for human-robot collaboration in manufacturing tasks. International Journal on Interactive Design and Manufacturing (IJIDeM), 11: 139-153.

[48] McKee, G. 2001. The Impact of Internet Virtual Reality on Global Carrying Capacity. International Journal of Futures Studies, 1, 1995-1997.

[49] Milgram, P., Kishino, F. 1994. A Taxonomy of Mixed Reality Visual Displays. IEICE Transactions of Information Systems, 77(12).

[50] Milicevic, M. 2017. The Future of Human Resources through Virtual Reality Lens. In: ARVRtech [online]. [cit. 2020-06-08]. Dostupné z: https://arvrtech.eu/blog/virtual-reality-helps-human-resources/

[51] Moore, E. 1998. Cramming More Components onto Integrated Circuits. Proceedings of the IEEE, 86(1): 82-85.

[52] Mujber, T. S., Szecsi, T., Hashmi, M. S. J. 2004. Virtual reality applications in manufacturing process simulation. Journal of Materials Processing Technology, 155-156: 1834-1838.

[53] Nash, B., Walker, A., Chambers, T. 2018. A simulator based on virtual reality to dismantle a research reactor assembly using master-slave manipulators. Ann Nucl Energy, 120:1-7.

[54] Nasios, K. 2002. Improving Chemical Plant Safety Training Using Virtual Reality. PhD thesis, University of Nottingham.

[55] Ong, S. K., Mannan, M. A. 2004. Virtual reality simulations and animations in a web-based interactive manufacturing engineering module. Computers \& Education, 43(4): 361-382.

[56] Ordaz, N., Romero, D., Gorecky, D., Siller, H. R. 2015. Serious games and virtual simulator for automotive manufacturing education \& training. Procedia Computer Science, 75: 267-274.

[57] Pantelidis, V. 2009. Reasons to Use Virtual Reality in Education and Training Courses and a Model to Determine When to Use Virtual Reality. Themes in Science and Technology Education, 2(2): 59 -70.

[58] Parkin, S. 2014. Oculus Rift. (cover story). MIT Technology Review, 117(3): 50-52.

[59] Peniche, A., Diaz, Ch., Paramo, G., Trefftz, H. 2012. Combining Virtual and Augmented Reality to Improve the Mechanical Assembly Training Process in Manufacturing. In Proceedings of the 6th WSEAS international conference on Computer Engineering and Applications, and Proceedings of the 2012 American conference on Applied Mathematics (AMERICANMATH'12/CEA'12). World Scientific and Engineering Academy and Society (WSEAS), Stevens Point, Wisconsin, USA, 292-297.

[60] Rabenstein, R. et al. 1997. Acoustic Rendering of Buildings. Proceedings of the 5th International IBPSA Conference Building Simulation, 2: 181-188. 
[61] Seth, A., Vance, J. M., Oliver, J. H. 2011. Virtual reality for assembly methods prototyping: a review. Virtual Reality, 15(1):5-20.

[62] Shin, Y.S. 2002. Virtual reality simulations in web-based science education. Computer Applications in Engineering Education, 10: 18-25.

[63] Shiratuddin, M., Zulkifli. A. 2001. Virtual Reality in Manufacturing. Ho Chi Minh City, Murdoch University.

[64] Siltanen, S. et al. 2010. Rays of Waves? Understanding the Strengths and Weaknesses of Computational Room Acoustics Modeling Techniques. Proceedings of International Symposium on Room Acoustics (ISRA2010), Melbourne, Australia.

[65] Streb, C. K., Voelpel, S. C. 2009. Analyzing the effectiveness of contemporary aging workforce management, Organizational Dynamics, 38(4): 305-311.

[66] Svensson, U. P. 2002. Modelling Acoustic Spaces for Audio Virtual Reality. Proceedings of the 1st IEEE Benelux Workshop on Model based Processing and Coding of Audio (MPCA), Leuven, Belgium.

[67] Syberfeldt, A., Danielsson, O., Holm, M., Wang, L. 2015. Visual assembling guidance using augmented reality. Procedia Manufacturing, 1: 98-109.

[68] Tesic, R., Banerjee, P. 1999. Exact collision detection using virtual objects in virtual reality modelling of a manufacturing process. J. Manufact. Syst, 18: 367-376.

[69] Trefftz, H., Peniche, A., Diaz, C., Paramo, G. 2011. An immersive virtual reality training system for mechanical assembly. In Recent Advances in Manufacturing Engineering, Proceedings of the 4th International Conference of Manufacturing Engineering, Quality and Production Systems (MEQAPS 11), 109-113.

[70] Unhelkar, V. V., Siu, H. C., Shah, J. A. 2014. Comparative performance of human and mobile robotic assistants in collaborative fetch-and-deliver tasks. In: Proc. 2014 ACM/IEEE Int. Conf. Human-robot Interact-HRI '14: 82-89.

[71] Unimersiv. 2016. How NASA is Using Virtual and Augmented Reality to Train Astronauts. In UNIMERSIV. [online]. [cit. 2020-06-08]. Dostupné z: https://unimersiv.com/how-nasa-is-using-virtual-and-augmented-reality-totrain-astronauts-37/

[72] Van Wyk, E., de Villiers, R. 2009. Virtual reality training applications for the mining industry. In Proceedings of the 6th International Conference on Computer Graphics, Virtual Reality, Visualisation and Interaction in Africa (AFRIGRAPH '09). Association for Computing Machinery, New York, NY, USA, Pp 53-63.

[73] Wainess, R., Kerr, D., Koenig, A. 2011. Improving the way we design games for learning by examining how popular video games teach. Los Angeles: CRESST.

[74] Waller, J. C., Foster, N. 2000. Training via the Web: A virtual instrument. Computers \& Education, 35: 161-167. 
[75] Wang, X., Ong, S. K., Nee, A. 2016. Multi-modal augmented-reality assembly guidance based on bare-hand interface. Advanced Engineering Informatics, 30(3): 406-421.

[76] Wickens, C. D. 2008. Situation awareness: review of Mica Endsley's 1995 articles on situation awareness theory and measurement. Hum. Factors, 50(3): 397-403.

[77] Whitman, L., Malzahn, D., Madhaven, V., Weheba, G., Krishnan, K., 2004. Virtual Reality Case Study throughout the Curriculum to Address Competency Gaps. Department of Industrial and Manufacturing Engineering, 20(5): 690-702. 